\section{Effects of Nitrogen Rates on Nitrogen, Phosphorous, and Potassium Partitioning, Accumulation, and Use Efficiency in Seepage-irrigated Fresh Market Tomatoes}

\author{
Monica Ozores-Hampton and Francesco Di Gioia ${ }^{1}$ \\ Institute of Food and Agricultural Sciences, South West Florida Research \\ and Education Center, University of Florida, Immokalee, FL 34142
}

\author{
Shinjiro Sato \\ Department of Science and Engineering for Sustainable Innovation, Soka \\ University 1-236 Tangimachi Hachiojishi, Tokyo 192-8577, Japan
}

Eric Simonne

Horticultural Sciences Department, University of Florida, Gainesville, FL 32611

Kelly Morgan

Institute of Food and Agricultural Sciences, South West Florida Research and Education Center, University of Florida, Immokalee, FL 34142

Additional index words. Solanum lycopersicum, nutrient management, nutrient accumulation, nutrient use efficiency, fertilization recommendation, Best Management Practices

\begin{abstract}
Florida had the largest fresh-market tomato (Solanum lycopersicum L.) production in the United States, with a value of $\$ 437$ million and 13,355 ha harvested in 2014. Despite the development of Best Management Practices (BMPs) and University of Florida/Institute of Food and Agricultural Sciences (UF/IFAS) fertilizer recommendations, tomato growers often use fertilizer rates above the recommended ones, especially when seepage irrigation is used and a longer growing season is foreseen. If a mass balance of $\mathrm{N}-\mathrm{P}-\mathrm{K}$ partitioning could be made in field conditions, a better understanding of nutrition applications could be reached. Therefore, a field study was conducted on seepage-irrigated tomato on a commercial farm in southwest Florida, during the spring and winter season of 2006 to evaluate the nitrogen (N) rate and season effects on tomato plant growth, fruit yield, $N$, phosphorous $(P)$, and potassium (K) accumulation and use efficiency. The UF/IFAS N-recommended rate (224

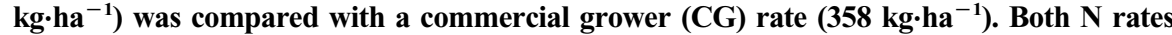
were incorporated at bedding with 61 and $553 \mathrm{~kg} \cdot \mathrm{ha}^{-1}$ of $P$ and $K$, respectively. Fruit yield and plant growth were measured and roots, stems, leaves, and fruit samples were analyzed to determine total $\mathbf{N}, \mathbf{P}$, and $K$ content and accumulation in different plant parts. Nutrient recovery (REC) and the partial factor of productivity of applied nutrients (PFP) were calculated for each $\mathrm{N}$ rate. In the spring, 120 days after transplanting, plants dry biomass was $11.5 \%$ higher $(P=0.01)$ in the CG $N$ rate than with UF/IFAS $N$ rate, while no significant differences were observed in the winter season. In the spring, $N$, $P$, and $K$ accumulation were 250,56 , and $285 \mathrm{~kg} \cdot \mathrm{ha}^{-1}$ in plants grown with CG $N$ rate and were significantly lower $(23 \%$, $5 \%$, and $23 \%$, respectively) with the UF/IFAS $N$ rate, respectively. In the winter, total $N$ accumulation was $231 \mathrm{~kg} \cdot \mathrm{ha}^{-1}$ in plants fertilized at CG $\mathrm{N}$ rate and significantly lower $(16 \%)$ with the UF/IFAS $N$ rate. $N$ rate did not significantly affect $P$ and $K$ accumulation, which were on average 64 and $312 \mathrm{~kg} \cdot \mathrm{ha}^{-1}$, respectively. Marketable fruit yield was significantly

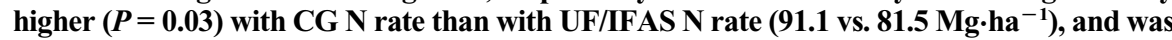
significantly higher $(P=0.03)$ in the spring than in the winter $\left(100.8 \mathrm{vs.} 71.8 \mathrm{Mg}^{-h^{-1}}\right)^{-1}$. The $\mathrm{N}_{\text {REC }}$ was significantly higher $(P=0.01)$ with the UF/IFAS $\mathrm{N}$ rate than with $\mathrm{CG} \mathrm{N}$ rate and was not significantly affected $(P=0.94)$ by seasons. The $P_{F P}$ was significantly higher $(P=$ $0.001)$ with the UF/IFAS N-rate than with CG N-rate, and was significantly higher $(P=0.04)$ in the spring than in the winter season. These results suggest that current UF/IFAS $\mathbf{N}$ recommendations are more conservative of $\mathbf{N}$ and this should lead to reduced leaching potential but, UF/IFAS recommendations must be season specific due to the difference in environmental conditions of fruit maturation in cooler weather of the winter season compared with a warmer environment of the spring season.
\end{abstract}

Received for publication 9 July 2015. Accepted for publication 2 Sept. 2015.

${ }^{1}$ Corresponding author. E-mail: fdigioia@ufl.edu.

Fresh-market tomato is the most important vegetable crop in Florida with a harvested area of 13,355 ha and a production value of $\$ 437$ million in 2014 (USDA, 2015). Florida accounted for $34 \%$ of the national freshmarket tomato harvested area and $39 \%$ of the national crop value (USDA, 2015). Florida tomato production is concentrated in the central and southern areas of the state on low water-holding capacity sandy soils. Tomatoes are grown on raised polyethylene-mulched beds, using predominately subsurface (seepage) irrigation (Dukes et al., 2010). Seepage irrigation consists of managing a perched water table on top of a slowly permeable soil layer ("spodic layer") located at $\approx 0.90$ to $1.50 \mathrm{~m}$ depth. Water is pumped from the ground or surface reservoirs into a series of canals and ditches and is delivered to the plants by capillarity (Smajstrla and Muñoz-Carpena, 2011). This irrigation method is widely used by Florida tomato's growers for its low technology and operating costs (Zotarelli et al., 2013). An additional benefit of seepage irrigation is the possibility to raise the water table near the soil surface as an attempt to increase air temperature of few degrees during freezing events (OzoresHampton et al., 2010). However, drainage of water after the freeze event or excessive rainfall may remove substantial amounts of nutrients from the root zone. In seepageirrigated tomato crops, Sato et al. (2012) estimated losses of $\mathrm{N}$ and $\mathrm{K}$ over $40 \%$ and $35 \%$ of initial $\mathrm{N}$ and $\mathrm{K}$ available, respectively. Moreover, seepage irrigation requires large amounts of water, and has an average water use efficiency of $30 \%$ to $50 \%$ (Locascio, 2005). Seepage irrigation is hence considered one of the least efficient irrigation methods and its use raises several concerns for its potential negative impact on the environment (Ozores-Hampton et al., 2012; Simonne et al., 2010).

In seepage-irrigated crops, all the nutrients $\mathrm{N}, \mathrm{P}$, and $\mathrm{K}$ are applied $100 \%$ at bed formation; $20 \%$ to $25 \%$ of $\mathrm{N}$ and $\mathrm{K}$ and $100 \%$ of $\mathrm{P}$ and micronutrients are broadcast applied into the bed as the "bottom mix"; the remaining $80 \%$ to $75 \%$ of $\mathrm{N}$ and $\mathrm{K}$ are applied in two grooves of 5 to $7 \mathrm{~cm}$ depth in the bed shoulders as the "hot mix" (Olson et al., 2005). As water moves upward into the root zone by capillarity, nutrients are slowly dissolved and made available for the crop (Sato et al., 2009a, 2009b). However, rainfalls events, water table rises for frost protection, and/or poor water management may cause surface runoff, denitrification or leaching of nutrients out of the root zone, with consequent negative impact on crop productivity and groundwater and surface water quality (Cockx and Simonne, 2014; Sato et al., 2009a, 2009b; Simonne and Morgant, 2005).

In an effort to reduce water pollution and improve the crop water and nutrient use efficiency (NUE), and in response to the Federal Total Maximum Daily Load mandate described in the Federal Clean Water Act (U.S. Environmental Protection Agency, 2010), the Florida Department of Agriculture and Consumer Services (FDACS) and the UF/ IFAS have developed and implemented BMPs. BMPs are cultural practices that aim at reducing the environmental impact of crop production while maintaining yields (FDACS, 2005), and "fertilization" and "irrigation" are 
two important cultural practices addressed in the BMPs.

Current UF/IFAS fertilization recommendations for tomato grown in Florida are based on preplanting soil tests for $\mathrm{P}, \mathrm{K}$, and micronutrients, with a blanket $\mathrm{N}$ rate of $224 \mathrm{~kg} \cdot \mathrm{ha}^{-1}$ for all growing seasons (fall, winter, and spring), tomato types (round, Roma, or grape), soil types (spodic or well-drained soils), and irrigation methods (drip or seepage; Olson et al., 2005). The recommendations allow for supplemental applications of $\mathrm{N}$ and $\mathrm{K} 1$ ) after a leaching rainfall event (defined as $76 \mathrm{~mm}$ of rain in $3 \mathrm{~d}$ or $102 \mathrm{~mm}$ in $7 \mathrm{~d}), 2$ ) when the results of foliar analysis or petiole sap testing are "low," or 3) in case of extended harvest seasons (Olson et al., 2005).

Despite these BMP recommendations, some tomato producers still apply $\mathrm{N}$ rates that range between 290 and $470 \mathrm{~kg} \cdot \mathrm{ha}^{-1}$ of $\mathrm{N}$ which is well above the UF/IFAS-recommended rate (Cantliffe et al., 2009). These higher $\mathrm{N}$ rates may be "justified" by: 1) the longer crop seasons (16, 20, or 18 weeks in south Florida for fall, winter, and spring plantings compared with 13 weeks in north Florida for spring plantings), 2) temporary water table rises during heavy rainfall periods and/or for frost protection events, and 3) the soil moisture conditions, more conducive to denitrification (Simonne and Morgant, 2005; Simonne and Ozores-Hampton, 2006). Although, studies on tomato yield response to $\mathrm{N}$ rates have been documented in the past and recently compiled by Hochmuth and Hanlon (2014), few studies have estimated the crop N, P, and K accumulation and partitioning, or have used the principle of the critical $\mathrm{N}$ concentration $\left(\% \mathrm{~N}_{\text {crit }}\right)$, defined as the minimum $\mathrm{N}$ concentration in the aerial biomass required for maximum growth (Greenwood et al., 1991), to evaluate the UF/ IFAS $\mathrm{N}$ recommended rate. Yet, very few studies have evaluated and compared tomato crop $\mathrm{N}$ response in different growing seasons, which seem to have a big influence on the crop productivity and thus on the demand of nutrients (Ozores-Hampton et al., 2006; Scholberg et al., 2000).

Therefore, a field study was conducted in southwest Florida on seepage-irrigated tomatoes comparing the UF/IFAS $\mathrm{N}$ rate (224 $\left.\mathrm{kg} \cdot \mathrm{ha}^{-1}\right)$ and a CG N rate $\left(358 \mathrm{~kg} \cdot \mathrm{ha}^{-1}\right)$ for two different (spring and winter) seasons to 1) evaluate the $\mathrm{N}$ rate and season effects on plant growth and fruit yield; 2) determine $\mathrm{N}, \mathrm{P}$, and $\mathrm{K}$ partitioning and accumulation in roots, stem, leaves, and fruits; 3 ) estimate the crop REC, the partial factor of PFP, and the potential return of nutrients to the soil with the crop residue; 4) analyze a posteriori the crop $\mathrm{N}$ status and fertilizer management following the principle of the $\% \mathrm{~N}_{\text {crit }}$ and using the $\mathrm{N}$ nutrition index (NNI) proposed by Lemaire et al. (1989).

\section{Materials and Methods}

Experimental site, treatments application, and growing conditions. Two trials were conducted on seepage-irrigated tomato during the spring and winter growing seasons of 2006 in a commercial farm located near Immokalee, FL $\left(26^{\circ} 25^{\prime} 11^{\prime \prime} \mathrm{N}, 81^{\circ} 25^{\prime} 19^{\prime \prime} \mathrm{W}\right)$. Soil types were typical Florida sandy soils in both trials: poorly drained Holopaw fine sand (loamy, siliceous, active, hyperthermic Grossarenic Endoaqualf) and Oldsmar fine sand (sandy, siliceous, hyperthermic Alfic Arenic Alaquod) for the spring and winter season, respectively (Sato et al., 2009a). For both trials, fertilizer treatments consisted of two $\mathrm{N}$ rates: the UF/ IFAS N recommended rate of $224 \mathrm{~kg} \cdot \mathrm{ha}^{-1}$ and a CG rate of $358 \mathrm{~kg} \cdot \mathrm{ha}^{-1}$. Nitrogen rates were applied in pretransplanting and incorporated at bedding with 61 and $553 \mathrm{~kg} \cdot \mathrm{ha}^{-1}$ of $\mathrm{P}$ and $\mathrm{K}$ fertilizer, respectively. Phosphorous and $\mathrm{K}$ rates were selected based on the common commercial practices in the area. The soil was rototilled and the bottom mix including $\mathrm{N}, \mathrm{P}$, and $\mathrm{K}$ [prepared with a blend of ammonium nitrate $\left(\mathrm{NH}_{4} \mathrm{NO}_{3}\right)$, superphosphate, and potassium sulfate $\left(\mathrm{K}_{2} \mathrm{SO}_{4}\right)$ ] was broadcast applied $(60 \mathrm{~cm}$ wide) to the soil surface, at the rate of 17,61 , and $27 \mathrm{~kg} \cdot \mathrm{ha}^{-1}$ of $\mathrm{N}, \mathrm{P}$, and $\mathrm{K}$, respectively. Then, $20-\mathrm{cm}$ tall raised beds were formed on 1.8 -m centers using a 90-cm-wide bed press. The top fertilizer mixes were then applied in two grooves on the shoulder of the bed at the rate of 207 or $341 \mathrm{~kg} \cdot \mathrm{ha}^{-1}$ of N and $526 \mathrm{~kg} \cdot \mathrm{ha}^{-1}$ of $\mathrm{K}$, using $\mathrm{NH}_{4} \mathrm{NO}_{3}$ and $\mathrm{K}_{2} \mathrm{SO}_{4}$. The beds were then fumigated with methyl bromide and chloropicrin $(67: 33, \mathrm{w} / \mathrm{w})$ at the rate of $224 \mathrm{~kg} \cdot \mathrm{ha}^{-1}$. The position of the shanks used to inject the fumigant was such that it did not affect the integrity of the fertilizer bands. All beds were covered with low-density black polyethylene mulch, immediately following the fumigant application. Two weeks after fumigation [on 4 Jan. and 26 Oct. 2006; these dates represented days after transplanting $(\mathrm{DAT})=0$ for each season], 6-week-old 'Florida 47 R' tomato seedlings (Seminis Seeds, Oxnard, CA) were transplanted $0.66 \mathrm{~m}$ apart in a single row for each bed, which created a population of 8274 plants per ha. In both trials, the field was seepage irrigated with a water furrow located every six beds. Pest control and other cultural practices followed UF/IFAS recommendations (Olson et al., 2005).

Weather data and irrigation management. Weather data were obtained by the Florida Automated Weather Network station located in Immokalee, FL (http://fawn.ifas.ufl.edu/). Irrigation was managed by maintaining the water table $\approx 40-70 \mathrm{~cm}$ below the bed surface to assure a constant upward capillary movement (upflux) of the water in the root zone (Stanley and Clark, 2003). Water table depth was monitored daily by the grower using monitoring wells installed in the center bed of each replication. The monitoring wells were constructed from 1.2-m-long, 10-cm-diameter polyvinyl chloride (PVC) pipes screened at the bottom $20 \mathrm{~cm}$ (Smajstrla and MuñozCarpena, 2011). A float was attached to one end of a PVC pipe to serve as the water level indicator. Permanent marks were made every $25 \mathrm{~mm}$ to indicate the water table depth below the plastic mulch bed. Weekly (spring season) and biweekly (winter season) observations of the water table depth were taken throughout the growing season from each well.

Plant dry biomass, tissue analyses, nutrient accumulation, and return to the soil at the end of the season. On 30,60, 90, and 120 DAT in the spring and 30, 70, and 100 DAT in the winter, roots, stems, leaves, and fruit from a plant randomly selected from the center bed of each plot, excluding border plants, were collected in labeled bags and oven dried at $65{ }^{\circ} \mathrm{C}$ until constant weight to determine dry weight (DW). Plant roots were collected, cutting the bed all around the plant with a shovel until reaching the maximum depth of the root system, then the root system was lifted and cleaned by hand; roots recovered were then rinsed with water, placed in labeled bags, and dried. Total plant dry matter accumulation was calculated as the sum of the roots, stems, leaves, and fruits DWs. Total Kjeldahl $\mathrm{N}$ was determined in each sample following the Kjeldahl method, with the addition of salicylic acid for the recovery of nitrate-N (Simonne et al., 1997), and using a semiautomated block digester, AAII (Kopp and McKee, 1983). Total $\mathrm{P}$ and total $\mathrm{K}$ were determined by dry ashing $\left(550{ }^{\circ} \mathrm{C}\right)$, acid dissolution $\left(0.5 \mathrm{~mol} \cdot \mathrm{L}^{-1} \mathrm{HCl}\right)$ of plant materials, followed by use of the spectrophotometer (DR/4000U; Hach Co., Loveland, CO) and an atomic absorption spectrophotometer (5100PC; PerkinElmer, Waltham, MA), respectively (Jones and Case, 1990). Nitrogen, P, and $\mathrm{K}$ accumulation in each plant portion was calculated by multiplying the DW by total Kjeldahl N, $\mathrm{P}$, and $\mathrm{K}$ concentrations, respectively. Total plant $\mathrm{N}, \mathrm{P}$, and $\mathrm{K}$ accumulation $\left(\mathrm{TN}_{\mathrm{acc}}\right)$ was calculated as the sum of nutrients accumulated in the roots, stems, leaves, and fruits. Since only fruits are removed from the field, nutrient return to the soil as crop residues was calculated as the sum of N, P, and K accumulated in roots, stems, and leaves at the end of each season. In both seasons, in correspondence of each biometric assessment the NNI was calculated as proposed by Lemaire et al. (1989), by dividing the measured $\mathrm{N}$ concentration of the aboveground biomass by the predicted $\% \mathrm{~N}_{\text {crit }}$ following the relationship defined by Tei et al. (2002) for tomato: $\% \mathrm{~N}_{\text {crit }}=4.53 \cdot \mathrm{DW}^{-0.327}$.

Fruit yield and grade distribution. Yield was measured in each plot on 6.6-m long, representative sections in the center bed of each plot. Tomatoes ranging from mature green to ripe in color were harvested three times on 100,120 , and 134 DAT for the spring season, and 83, 98, and 112 DAT for the winter season, and graded into extra-large (diameter greater than $7.00 \mathrm{~cm})$, large $(6.35$ to $7.00 \mathrm{~cm})$, medium $(5.72$ to $6.43 \mathrm{~cm})$, and cull fruit according to the U.S. Standards for Grades of Fresh Tomatoes (USDA, 1997).

Soil analysis, REC, and PFP. An estimate of the REC was calculated for each nutrient $\left(\mathrm{N}_{\mathrm{REC}}, \mathrm{P}_{\mathrm{REC}}\right.$, and $\left.\mathrm{K}_{\mathrm{REC}}\right)$ according to Sato et al. (2012) as:

$$
\mathrm{REC}=\frac{100 \% \times\left(\mathrm{TN}_{\mathrm{acc}}\right)}{(\mathrm{SNC}+\mathrm{FA}+\mathrm{M})}
$$

where $\mathrm{TN}_{\mathrm{acc}}$ was the total plant nutrient accumulation $\left(\mathrm{kg} \cdot \mathrm{ha}^{-1}\right)$, SNC was the preplant soil nutrient content $\left(\mathrm{kg} \cdot \mathrm{ha}^{-1}\right)$, FA was the amount of fertilizer applied $\left(\mathrm{kg} \cdot \mathrm{ha}^{-1}\right)$, and $\mathrm{m}$ was the amount of inorganic $\mathrm{N}\left(\mathrm{N}_{\mathrm{i}}\right)$ deriving from the mineralization process. 
The amount of nutrients supplied to the crop with the irrigation water was considered negligible and therefore was not accounted in Eq. [1]. Preplant total inorganic $\mathrm{N}\left(\mathrm{TN}_{\mathrm{i}}\right)$, Mehlich-1 extractable P (TM1-P), and K (TM1-K) content in the soil beds were estimated on a field basis to a depth of $30 \mathrm{~cm}$ as described by Sato et al. (2012), based on initial $\mathrm{N}_{\mathrm{i}}, \mathrm{M}-1 \mathrm{P}$, and M1-K concentration of the soil for both seasons. Initial $\mathrm{N}_{\mathrm{i}}$ was estimated as the sum of ammonium-N and nitrate- $\mathrm{N}$ extracted using $2 \mathrm{~mol} \mathrm{~L}^{-1} \mathrm{KCl}$ and determined colorimetrically by a salicylate-hypochlorite method and a Cadmium reduction method, respectively (Mulvaney, 1996). To extract available $P$, soil samples were analyzed using a sequential extraction following a modified procedure of Tiessen and Moir (1993), and M-1 P was determined by a spectrophotometer (DR/4000U) at $880 \mathrm{~nm}$. Mehlich-1 K (Mehlich, 1978) was determined by an atomic absorption spectrophotometer (5100PC). Gravimetric soil water content was determined by drying soil at $105^{\circ} \mathrm{C}$ for $24 \mathrm{~h}$ to calculate the concentrations of all nutrients on a dry soil weight basis. Nitrogen mineralization amount $\left(\mathrm{M}_{\mathrm{N}}\right)$ was adapted from the average $\mathrm{N}$ mineralization rates estimated as TN extracted using the electro-ultrafiltration (EUF) method from soil type similar to Holopaw and Oldsmar for the spring and winter seasons, respectively (Dou et al., 2000).

Total fruit yields obtained in both seasons were used to determine for each level of $\mathrm{N}$ supply the partial factor of PFP, which represents the kilograms of product harvested per kilogram of nutrient fertilizer applied, and calculated as:

$$
\mathrm{PFP}=\frac{\mathrm{YF}}{\mathrm{N}_{\mathrm{FA}}}
$$

where YF was the total fruit yield $\left(\mathrm{kg} \cdot \mathrm{ha}^{-1}\right)$ obtained with the application of a determinate rate $\left(\mathrm{kg} \cdot \mathrm{ha}^{-1}\right)$ of nutrient fertilizer applied $\left(\mathrm{N}_{\mathrm{FA}}\right)$. The same equation was used to determine the partial factor of productivity of applied $\mathrm{N}\left(\mathrm{PFP}_{\mathrm{N}}\right), \mathrm{P}\left(\mathrm{PFP}_{\mathrm{P}}\right)$, and $\mathrm{K}\left(\mathrm{PFP}_{\mathrm{K}}\right)$.

Experimental design and statistical analysis. In both trials, $\mathrm{N}$ treatments were arranged in 365-m long plots that included six adjacent beds according to a randomized complete block design with three replications. Using the GLM procedure in SAS software package (SAS Version 9.1; SAS Institute Inc., Cary, NC), the analysis of variance was performed to evaluate the effect of $\mathrm{N}$ rates and season on dry biomass accumulation, $\mathrm{N}, \mathrm{P}$, and $\mathrm{K}$ accumulation and return, REC, PFP, NNI, and fruit yield. When the interaction $\mathrm{N}$ rate $\times$ season was significant, data were analyzed separately by season and by sampling date comparing UF/IFAS $\mathrm{N}$ recommended rate and the $\mathrm{CG} \mathrm{N}$ rate.

\section{Results and Discussion}

Weather conditions and water table depth. Daily air temperatures on average were 19.8 and $19.4{ }^{\circ} \mathrm{C}$ in the spring and winter season, respectively. In the spring season, daily minimum and maximum air temperature ranged from -2.5 to $20.9^{\circ} \mathrm{C}$ and from 15.5 to $36.8^{\circ} \mathrm{C}$, respectively (Fig. 1). Two freezing events were recorded during the spring season, one at the beginning of January, 5 DAT, and the second in mid-February, 41 DAT. The relatively low temperature observed at the beginning of the season may have contributed to extend the length of the crop season to 19 weeks. The winter season was shorter (16 weeks) than regular south Florida winter seasons (20 weeks). Daily minimum and maximum air temperature ranged from -0.1 to $20.4{ }^{\circ} \mathrm{C}$ and from 15.5 to $32.4{ }^{\circ} \mathrm{C}$, respectively. During the winter season, a single freezing event occurred on 30 Jan., toward the end of the season (96 DAT). Daily solar irradiance was on average 231.5 and $138.8 \mathrm{~W} \cdot \mathrm{m}^{-2}$ in the spring and winter seasons, respectively. Cumulative precipitations were
$146 \mathrm{~mm}$ in the spring and $33 \mathrm{~mm}$ in the winter season (Fig. 1), which may be considered low as compared with cumulative rainfall in typical southwest Florida spring and winter seasons (Fraisse et al., 2010). Based on the definition of leaching rainfall provided by Olson et al. (2005), no leaching rainfall events were recorded in either growing season. Therefore, no supplemental post-transplanting applications of $\mathrm{N}$ and $\mathrm{K}$ were allowed/needed according the UF/IFAS recommendation (Olson et al., 2005). Water table depth in the monitoring wells fluctuated between 26 to 79 and 38 to $66 \mathrm{~cm}$ in the spring and winter season, respectively (Fig. 2). The water table was closer to the bed top during the first 4 weeks after
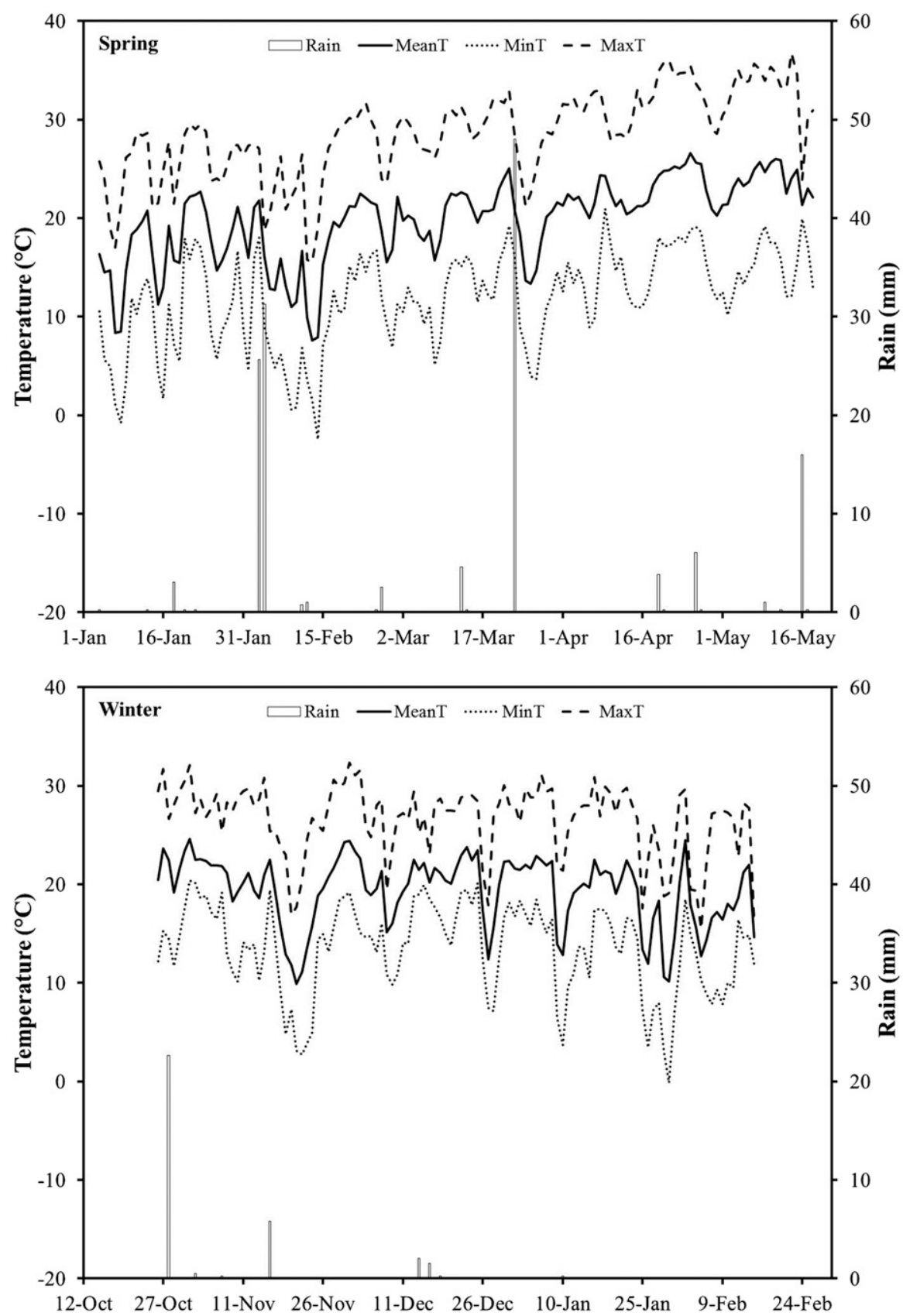

Fig. 1. Daily mean, minimum, maximum temperatures and rainfall recorded in the 2006 spring and winter growing seasons at the Florida Automated Weather Network station located at the University of Florida/Institute of Food and Agricultural Science, southwest Florida Research and Education Center in Immokalee, FL, at $18.5 \mathrm{~km}$ of distance from the field. 


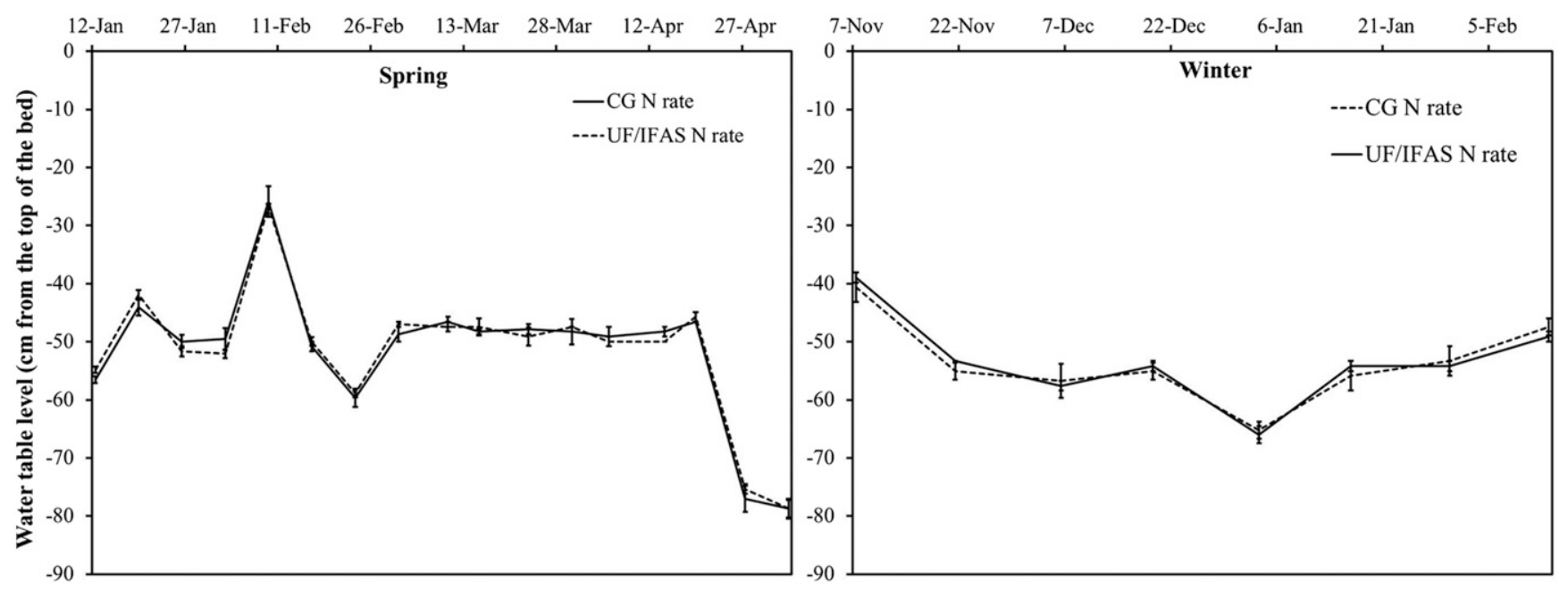

Fig. 2. Water table levels (centimeters from the top of the bed) observed in seepage-irrigated 'Florida $47 \mathrm{R}$ ' tomato crops grown during the spring and winter season of 2006 in Immokalee, FL. Means of three replications. Vertical bars represent $\pm \mathrm{SE}$.

planting, when the water level was raised to enhance the plant establishment, and as a result of rainfall events recorded during the spring season in February $(61.5 \mathrm{~mm})$ and March $(52.8 \mathrm{~mm})$ of 2006 . Moreover, the water table was raised for frost protection in correspondence of the second freezing event recorded at 41 DAT during the spring (Fig. 2). Since the field was managed as a single hydrological unit, as expected, the water table depths recorded weekly during the spring or biweekly in the winter season indicated no differences in water table fluctuations between $\mathrm{N}$ rate treatments (Fig. 2).

Plant growth and dry biomass partitioning. Significant interactions were observed between $\mathrm{N}$ rate and seasons. Therefore plant growth data were analyzed separately for each season and by sampling date within each season. In the spring trial, $\mathrm{N}$ rate effects on the total plant dry biomass production at 30 , 60 , and 90 DAT were not significant $(P=0.55$, 0.40 , and 0.71 , respectively). On 120 DAT, plants receiving the $\mathrm{CG} \mathrm{N}$ rate showed significantly $(P=0.01)$ higher $(11.5 \%)$ total plant DW than those fertilized with the UF/IFAS N rate (Table 1). With the exception of the fruit DW at 60 DAT, that was 2.5 times higher with $\mathrm{CG} \mathrm{N}$ rate than at UF/IFAS $\mathrm{N}$ rate, roots, stems, leaves, and fruit DW were not significantly affected by $\mathrm{N}$ rate in any of the sampling dates. Observed shoot (leaves and stems) and fruit dry biomass accumulations (on average 4.25 and $5.05 \mathrm{Mg} \cdot \mathrm{ha}^{-1}$, respectively) were higher than those values (on average 1.88 and $2.27 \mathrm{Mg} \cdot \mathrm{ha}^{-1}$, respectively) reported by Zotarelli et al. (2009a) for the same tomato cultivar grown in north Florida for three consecutive spring seasons, using drip irrigation, with $\mathrm{N}$ rates ranging from 220 to $330 \mathrm{~kg} \cdot \mathrm{ha}^{-1}$.

In the winter season, roots, stems, leaves, fruit, and total plant DW were not significantly affected by $\mathrm{N}$ rates on all the sampling dates, with the exception of the roots DW at $30 \mathrm{DAT}$ and the fruit DW at $100 \mathrm{DAT}$. On these dates, they were on average $25.5 \%$ $(P=0.03)$ and $9.2 \%(P=0.02)$ higher,

Table 1. Nitrogen (N) commercial grower $\left(358 \mathrm{~kg} \cdot \mathrm{ha}^{-1}\right)$ and University of Florida/Institute of Food and Agricultural Sciences $\left(224 \mathrm{~kg} \cdot \mathrm{ha}^{-1}\right)$ rate effects on dry matter partitioning in 'Florida $47 \mathrm{R}$ ' tomato plants grown with seepage irrigation during the spring and winter seasons of 2006 in Immokalee, FL. ${ }^{z}$

\begin{tabular}{|c|c|c|c|c|c|c|}
\hline \multirow[b]{2}{*}{$\mathrm{DAT}^{\mathrm{y}}$} & \multirow[b]{2}{*}{$\mathrm{N}$ rate $\left(\mathrm{kg} \cdot \mathrm{ha}^{-1}\right)$} & \multicolumn{5}{|c|}{ Dry wt $\left(\mathrm{kg} \cdot \mathrm{ha}^{-1}\right)$} \\
\hline & & Roots & Stem & Leaves & Fruits & Total \\
\hline \multirow{3}{*}{30} & & & Spring seasor & & & \\
\hline & 224 & 31 & 39 & 163 & 0 & 232 \\
\hline & 358 & 36 & 44 & 184 & 0 & 265 \\
\hline$P$ value & & 0.63 & 0.29 & 0.58 & - & 0.55 \\
\hline \multirow{2}{*}{60} & 224 & 102 & 433 & 1,437 & 78 & 2,050 \\
\hline & 358 & 93 & 433 & 1,396 & 194 & 2,116 \\
\hline$P$ value & & 0.60 & 0.99 & 0.30 & 0.02 & 0.40 \\
\hline \multirow{2}{*}{90} & 224 & 83 & 1,003 & 2,464 & 3,407 & 6,957 \\
\hline & 358 & 80 & 1,012 & 2,453 & 3,719 & 7,264 \\
\hline$P$ value & & 0.80 & 0.96 & 0.96 & 0.44 & 0.71 \\
\hline \multirow{2}{*}{120} & 224 & 79 & 1,317 & 2,773 & 4,716 & 8,885 \\
\hline & 358 & 119 & 1,478 & 2,930 & 5,384 & 9,911 \\
\hline \multirow[t]{2}{*}{$P$ value } & & 0.14 & 0.59 & 0.65 & 0.36 & 0.01 \\
\hline & & & Winter seaso & & & \\
\hline \multirow{2}{*}{30} & 224 & 31 & 93 & 342 & 0 & 466 \\
\hline & 358 & 39 & 118 & 373 & 0 & 531 \\
\hline \multirow[t]{3}{*}{$P$ value } & & 0.02 & 0.10 & 0.23 & - & 0.08 \\
\hline & 224 & 95 & 638 & 1,702 & 1,188 & 3,622 \\
\hline & 358 & 97 & 708 & 1,889 & 1,391 & 4,085 \\
\hline \multicolumn{2}{|l|}{$P$ value } & 0.90 & 0.55 & 0.54 & 0.10 & 0.37 \\
\hline \multirow{2}{*}{100} & 224 & 180 & 918 & 2,478 & 3,338 & 6,915 \\
\hline & 358 & 136 & 879 & 2,384 & 3,731 & 7,129 \\
\hline$P$ value & & 0.52 & 0.51 & 0.06 & 0.002 & 0.08 \\
\hline
\end{tabular}

${ }^{2}$ Reported values are averages of three replications. Means in bold are significantly different at $P=0.05$. ${ }^{\mathrm{y}} \mathrm{DAT}=$ Days after transplanting.

respectively, in plants fertilized with $\mathrm{CG}$ $\mathrm{N}$ rate as compared with the UF/IFAS $\mathrm{N}$ rate (Table 1). Comparing the two seasons, the significantly lower $(P=0.02)$ total plant DW observed in the winter may be explained by the shorter crop cycle and lower solar radiation level recorded during the winter season. These results were consistent with those of Scholberg et al. (2000), which reported lower total plant dry biomass accumulation in fall tomato crops than in spring crops (on average 5,370 vs. $6,411 \mathrm{~kg} \cdot \mathrm{ha}^{-1}$ with 262 and $269 \mathrm{~kg}$ of $\mathrm{N}$, respectively), suggesting that crop response to $\mathrm{N}$ supply in terms of biomass production is influenced by the planting dates and the length of the growing season.
During the spring season, at 30 and 60 DAT, $70 \%$ of the total plant DW was constituted by leaves, and together, leaves and stems accounted for $90 \%$ of the total plant DW. While at 90 and 120 DAT, at least $50 \%$ of the total plant DW was allocated in the fruit. The root dry biomass accounted for $13.5 \%$ to $1 \%$ of the total plant DW at 30 and 120 DAT, respectively (Table 1). Similarly, in the winter season, at $30 \mathrm{DAT}$, leaves, stems, and fruit represented $71.8 \%, 21.1 \%$, and $7.0 \%$ of the total plant DW, respectively. Whereas, at 70 and $100 \mathrm{DAT}$, the dry matter allocated to leaves and stems decreased to $64.1 \%$ and $47.4 \%$ of the total plant DW, respectively; and the dry matter allocated to fruit increased to $33.4 \%$ and $50.3 \%$ at 70 and 100 DAT, 
respectively (Table 1 ). The final DW partitioning between fruit, leaves, and stems observed during the two seasons were consistent with the values reported by other studies for fresh market (Zotarelli et al., 2009a) and processing (Elia and Conversa, 2012) tomatoes, suggesting that the plant DW partitioning is stable across different environments and tomato genotypes.

Fruit yield and grade distribution. No significant interaction was observed between $\mathrm{N}$ rate and seasons for the fruit yield, therefore yield data of the two seasons were analyzed together (Table 2). At first harvest and first and second harvest combined (FSHC), the $\mathrm{N}$ rate did not show any significant $(P=0.06$ and $P=0.16$, respectively) effect on the total marketable yield, and only FSHC large tomato production was $35 \%$ higher $(P=0.001)$ in plants fertilized with CG, than in those fertilized with UF/IFAS N rate. Total season marketable yield and total season large and mean fruit were $12 \%(P=0.03), 19 \%(P=0.05)$, and $36 \%$ $(P=0.002)$ higher, respectively, with CG N rate as compared with UF/IFAS N rate. While total season extra-large fruit and cull were not significantly $(P=0.76$ and $P=0.22$, respectively) affected by the $\mathrm{N}$ rate (Table 2 ). The growing season significantly influenced first $(P=0.01)$, FSHC $(P=0.01)$, and total season $(P=0.03)$ marketable yields, which were $80 \%$, $57 \%$, and $29 \%$ lower, respectively, in the winter as compared with the spring season (Table 2). These results were consistent with the lower total plant dry biomass observed in the winter as compared with the spring, and may be explained by the shorter winter crop cycle, and lower daily radiation and temperatures at fruit maturity. Total season marketable yields obtained during the spring were similar to those reported by Ozores-Hampton et al. (2012) for the same tomato cultivar grown on sandy soils during two spring seasons, with seepage irrigation and with different $\mathrm{N}$ fertilizer rates. However, observed season yields were consistently higher than those reported by Zotarelli et al. (2009b) for the same tomato cultivar, grown in north Florida for three consecutive spring seasons, using drip irrigation with $\mathrm{N}$ rates ranging between 176 and $330 \mathrm{~kg} \cdot \mathrm{ha}^{-1}$, suggesting that irrigation system and location may have a major effect on tomato fruit yield. Similarly, the total marketable yields observed in the winter were comparable to those recorded during the winter seasons by Ozores-Hampton et al. (2006) for tomato crops grown in south Florida either with seepage or drip irrigation. Overall, results suggest that tomato yield response to $\mathrm{N}$ may be influenced by growing season, irrigation system, and location within the state, therefore these three factors should be adequately considered in the formulation of $\mathrm{N}$ fertilizer recommendations.

Nutrient $(N, P$, and $K$ ) accumulation and partitioning. Significant interactions were observed between $\mathrm{N}$ rate and seasons, therefore nutrient accumulation data were analyzed by season and by sampling date within each season. In the two seasons, total nutrient accumulation ranged from 192 to $250 \mathrm{~kg} \cdot \mathrm{ha}^{-1}$ for $\mathrm{N}, 53$ to $67 \mathrm{~kg} \cdot \mathrm{ha}^{-1}$ for $\mathrm{P}$, and 221 to $318 \mathrm{~kg} \cdot \mathrm{ha}^{-1}$ for $\mathrm{K}$ (Table 3 ). In the spring, $\mathrm{N}$

Table 2. Fruit weight distribution for first harvest, first and second harvest combined, and season total harvest (three harvests combined) of seepage-irrigated 'Florida $47 \mathrm{R}$ ' tomato grown with two $\mathrm{N}$ rates during the spring and winter season of 2006 in Immokalee, FL.

\begin{tabular}{|c|c|c|c|c|c|c|c|c|c|c|c|c|c|}
\hline & \multicolumn{4}{|c|}{ First harvest $\left(\mathrm{Mg} \cdot \mathrm{ha}^{-1}\right)$} & \multicolumn{4}{|c|}{ First and second harvest $\left(\mathrm{Mg} \cdot \mathrm{ha}^{-1}\right)$} & \multicolumn{5}{|c|}{ Total season harvest $\left(\mathrm{Mg} \cdot \mathrm{ha}^{-1}\right)$} \\
\hline & $\mathrm{XL}^{\mathrm{y}}$ & $\mathrm{L}$ & M & TMY & $\mathrm{XL}$ & $\mathrm{L}$ & M & TMY & XL & $\mathrm{L}$ & M & TMY & Cull \\
\hline \multicolumn{14}{|l|}{$\mathrm{N}$ rate $\left(\mathrm{kg} \cdot \mathrm{ha}^{-1}\right)$} \\
\hline 224 & 23.90 & 4.74 & 0.55 & 29.19 & 42.19 & 11.02 & 4.48 & 57.68 & 52.49 & 17.90 & 11.13 & 81.52 & 7.87 \\
\hline 358 & 24.50 & 6.42 & 0.76 & 31.67 & 41.65 & 14.88 & 4.49 & 61.02 & 53.42 & 24.37 & 13.29 & 91.09 & 9.18 \\
\hline \multicolumn{14}{|l|}{ Season } \\
\hline Spring & 39.41 & 10.06 & 1.18 & 50.65 & 59.03 & 18.18 & 5.57 & 82.77 & 64.21 & 25.30 & 11.29 & 100.81 & 10.15 \\
\hline Winter & 8.99 & 1.09 & 0.13 & 10.21 & 24.81 & 7.71 & 3.41 & 35.93 & 41.7 & 16.97 & 13.13 & 71.80 & 6.90 \\
\hline \multicolumn{14}{|l|}{$P$ values } \\
\hline $\mathrm{N}$ rate & 0.64 & 0.12 & 0.19 & 0.06 & 0.80 & 0.001 & 0.98 & 0.16 & 0.76 & 0.002 & 0.05 & 0.03 & 0.22 \\
\hline Season & 0.00 & 0.04 & 0.05 & 0.01 & 0.002 & 0.02 & 0.20 & 0.01 & 0.02 & 0.05 & 0.15 & 0.03 & 0.25 \\
\hline $\mathrm{N}$ rate $\times$ season & 0.82 & 0.29 & 0.88 & 0.24 & 0.93 & 0.09 & 0.79 & 0.62 & 0.56 & 0.14 & 0.50 & 0.22 & 0.24 \\
\hline
\end{tabular}

${ }^{\mathrm{z}}$ Reported values are averages of three replications. Means in bold are significantly different at $P=0.05$.

${ }^{\mathrm{y}} \mathrm{XL}=$ Extra-large $[$ diameter(D) $>7.00 \mathrm{~cm}$ ]; $\mathrm{L}=\operatorname{large}(6.35<\mathrm{d}<7.00 \mathrm{~cm}) ; \mathrm{m}=$ medium $(5.72<\mathrm{d}<6.43 \mathrm{~cm}) ;$ TMY $=$ total marketable yield.

Table 3. Nitrogen rate effects on N nutrition index (NNI), N, P, and K accumulation and partitioning in 'Florida 47 R' tomato plants grown with seepage irrigation during the spring and winter seasons of 2006 in Immokalee, FL. ${ }^{\mathrm{z}}$

\begin{tabular}{|c|c|c|c|c|c|c|c|c|c|c|c|c|c|c|c|c|c|}
\hline \multirow[b]{2}{*}{$\mathrm{DAT}^{\mathrm{y}}$} & \multirow{2}{*}{$\begin{array}{c}\text { N rate } \\
\left(\mathrm{kg} \cdot \mathrm{ha}^{-1}\right)\end{array}$} & \multirow[b]{2}{*}{ NNI } & \multicolumn{5}{|c|}{$\mathrm{N}$ accumulation $\left(\mathrm{kg} \cdot \mathrm{ha}^{-1}\right)$} & \multicolumn{5}{|c|}{$\mathrm{P}$ accumulation $\left(\mathrm{kg} \cdot \mathrm{ha}^{-1}\right)$} & \multicolumn{5}{|c|}{$\mathrm{K}$ accumulation $\left(\mathrm{kg} \cdot \mathrm{ha}^{-1}\right)$} \\
\hline & & & Roots & Stems & Leaves & Fruits & Total & Roots & Stems & Leaves & Fruits & Total & Roots & Stems & Leaves & Fruits & Total \\
\hline \multicolumn{18}{|c|}{ Spring season } \\
\hline \multirow{2}{*}{30} & 224 & 1.09 & 0.68 & 1.62 & 9.26 & 0.00 & 11.56 & 0.19 & 0.33 & 1.31 & 0.00 & 1.83 & 0.71 & 2.60 & 5.68 & 0.00 & 8.99 \\
\hline & 358 & 1.09 & 0.83 & 1.84 & 10.56 & 0.00 & 13.23 & 0.19 & 0.37 & 1.48 & 0.00 & 2.04 & 0.72 & 3.12 & 6.77 & 0.00 & 10.61 \\
\hline \multicolumn{2}{|l|}{$P$ values } & 0.91 & 0.56 & 0.30 & 0.59 & - & 0.55 & 0.91 & 0.34 & 0.77 & - & 0.68 & 0.96 & 0.08 & 0.60 & - & 0.51 \\
\hline \multirow{2}{*}{60} & 224 & 1.03 & 2.05 & 15.58 & 72.00 & 1.92 & 91.55 & 0.53 & 4.17 & 13.45 & 0.55 & 18.70 & 2.15 & 21.73 & 47.13 & 2.88 & 73.89 \\
\hline & 358 & 1.08 & 1.78 & 14.95 & 71.26 & 5.61 & 93.61 & 0.42 & 4.04 & 12.54 & 1.38 & 18.38 & 1.66 & 22.02 & 48.46 & 8.69 & 80.83 \\
\hline \multicolumn{2}{|l|}{$P$ values } & 0.15 & 0.42 & 0.55 & 0.80 & 0.01 & 0.40 & 0.21 & 0.78 & 0.36 & 0.01 & 0.82 & 0.26 & 0.95 & 0.82 & 0.04 & 0.56 \\
\hline \multirow{2}{*}{90} & 224 & 0.99 & 1.11 & 17.00 & 72.40 & 85.10 & 175.50 & 0.20 & 6.10 & 16.50 & 23.90 & 46.80 & 0.80 & 21.40 & 53.20 & 126.10 & 201.50 \\
\hline & 358 & 1.20 & 1.21 & 20.60 & 89.90 & 106.60 & 218.30 & 0.20 & 4.80 & 14.70 & 27.20 & 46.90 & 0.80 & 20.40 & 45.70 & 165.60 & 232.50 \\
\hline \multicolumn{2}{|l|}{$P$ values } & 0.05 & 0.62 & 0.32 & 0.20 & 0.09 & 0.15 & 0.26 & 0.19 & 0.26 & 0.46 & 0.98 & 0.49 & 0.88 & 0.58 & 0.14 & 0.45 \\
\hline \multirow{2}{*}{120} & 224 & 0.85 & 1.38 & 14.20 & 58.70 & 117.90 & 192.10 & 0.30 & 5.30 & 14.10 & 33.10 & 52.70 & 0.70 & 11.50 & 34.40 & 174.20 & 220.80 \\
\hline & 358 & 1.06 & 1.95 & 22.40 & 69.30 & 156.80 & 250.40 & 0.20 & 3.70 & 12.70 & 38.90 & 55.60 & 0.70 & 12.50 & 33.30 & 238.50 & 285.00 \\
\hline \multicolumn{2}{|l|}{$P$ values } & 0.02 & 0.39 & 0.14 & 0.26 & 0.20 & 0.05 & 0.86 & 0.12 & 0.17 & 0.33 & 0.58 & 0.92 & 0.73 & 0.63 & 0.03 & $\mathbf{0 . 0 2}$ \\
\hline \multicolumn{18}{|c|}{ Winter season } \\
\hline \multirow{2}{*}{30} & 224 & 1.26 & 0.45 & 4.49 & 22.48 & 0.00 & 27.42 & 0.22 & 0.94 & 3.87 & 0.00 & 5.03 & 0.50 & 6.48 & 14.10 & 0.00 & 21.09 \\
\hline & 358 & 1.16 & 0.47 & 4.79 & 24.06 & 0.00 & 29.32 & 0.21 & 1.28 & 4.15 & 0.00 & 5.65 & 0.30 & 8.47 & 14.75 & 0.00 & 23.52 \\
\hline \multicolumn{2}{|l|}{$P$ values } & 0.40 & 0.85 & 0.62 & 0.71 & - & 0.60 & 0.80 & 0.02 & 0.43 & - & 0.10 & 0.35 & 0.04 & 0.72 & - & 0.19 \\
\hline \multirow{2}{*}{70} & 224 & 1.33 & 1.50 & 26.50 & 63.80 & 29.50 & 121.20 & 0.70 & 8.10 & 19.50 & 9.10 & 37.40 & 1.90 & 41.40 & 93.50 & 49.00 & 185.60 \\
\hline & 358 & 1.24 & 1.40 & 22.60 & 73.70 & 40.50 & 138.30 & 0.70 & 9.20 & 22.10 & 11.90 & 43.80 & 2.10 & 57.10 & 117.80 & 62.60 & 239.50 \\
\hline \multicolumn{2}{|l|}{$P$ values } & 0.79 & 0.54 & 0.73 & 0.48 & 0.08 & 0.44 & 0.86 & 0.60 & 0.57 & 0.03 & 0.36 & 0.55 & 0.15 & 0.40 & 0.02 & 0.22 \\
\hline \multirow{2}{*}{100} & 224 & 1.15 & 3.00 & 19.30 & 85.40 & 86.20 & 193.90 & 1.20 & 10.40 & 24.60 & 25.50 & 61.70 & 3.80 & 58.10 & 110.60 & 137.20 & 309.70 \\
\hline & 358 & 1.35 & 2.20 & 19.90 & 99.60 & 108.90 & 230.60 & 0.80 & 10.30 & 24.00 & 31.90 & 66.90 & 3.10 & 48.30 & 97.70 & 168.50 & 317.60 \\
\hline \multicolumn{2}{|l|}{$P$ values } & 0.05 & 0.54 & 0.86 & 0.04 & 0.02 & 0.002 & 0.52 & 0.67 & 0.82 & 0.08 & 0.31 & 0.70 & 0.41 & 0.48 & 0.02 & 0.80 \\
\hline
\end{tabular}

${ }^{\mathrm{z}}$ Reported values are averages of three replications. Means in bold are significantly different at $P=0.05$.

${ }^{\mathrm{y}} \mathrm{DAT}=$ Days after transplanting. 
rates did not significantly affect total $\mathrm{N}, \mathrm{P}$, and $\mathrm{K}$ accumulation at 30,60 , and 90 DAT. Though, at 120 DAT, CG showed a total N and $\mathrm{K}$ accumulation $30.3 \%(P=0.05)$ and $29.1 \%(P=0.02)$ higher than UF/IFAS N rate, respectively, whereas no significant $(P=0.58)$ differences were observed for the total $\mathrm{P}$ accumulation (Table 3 ). In the winter season, $\mathrm{N}$ rate showed no significant effects on the total $\mathrm{N}, \mathrm{P}$, and $\mathrm{K}$ accumulation in any of the sampling dates, except at $100 \mathrm{DAT}$, when the total $\mathrm{N}$ accumulation was significantly higher $(18.9 \% ; P=0.003)$ with CG than with UF/IFAS $\mathrm{N}$ rate (Table 3 ). Total $\mathrm{N}$ accumulation in both seasons were similar to those reported for seepage-irrigated tomato by Scholberg et al. (2000), while were higher than values estimated by Zotarelli et al. (2009a) with the same tomato cultivar grown in sandy soils with drip irrigation and similar $\mathrm{N}$ rates. The higher $\mathrm{P}$ accumulation observed during the winter season, despite the shorter crop cycle, may be explained by the considerably higher initial total soil $\mathrm{P}$ content observed in the winter as compared with the spring season (Table 4).

Despite the shorter crop cycle and the lower preplant soil $\mathrm{K}$ content, total $\mathrm{K}$ accumulation was higher in the winter than in the spring season. Given the high mobility of $\mathrm{K}$ in sandy soils, this result may be explained at least in part by the higher fluctuations of the water table depth observed during the spring as consequence of the water table raise (up to $26 \mathrm{~cm}$ from the top of the bed) for frost protection at the beginning of the season and of the higher rainfall, which resulted in higher loss of $\mathrm{K}$ in the spring $(37 \%)$ as compared with the winter $(15 \%)$ season as estimated by Sato et al. (2012).

In accordance with other studies (DevienneBarret et al., 2000), these results suggest that the amount of nutrients available in the soil solution has a major influence on the plant nutrients accumulation, and therefore all the factors influencing the soil nutrients available for plant uptake can affect the final crop nutrients accumulated. Nevertheless, in agreement with the findings of Gastal and Lemaire (2002) and Tei et al. (2002), this study supports the hypothesis that when availability of nutrients is not a limiting factor, nutrients accumulation is strictly related to the crop dry biomass accumulation and partitioning within the plant. In fact, analyzing the nutrients partitioning over time, during the spring season, at 30 and $60 \mathrm{DAT}$, leaves and stems were the major allocation for $\mathrm{N}, \mathrm{P}$, and $\mathrm{K}$, accounting for over $90 \%$ of the nutrients accumulated. While at 90 and 120 DAT, over $50 \%$ of N, P, and $\mathrm{K}$ were allocated to the fruits. During the spring season, $\mathrm{N}, \mathrm{P}$, and $\mathrm{K}$ allocated to the roots accounted for $6.1 \%, 9.8 \%$, and $7.3 \%$ at 30 DAT, to $0.7 \%, 0.5 \%$, and $0.3 \%$ at 120 DAT, respectively (Table 2). Similarly, during the winter season at 30 DAT, 98.4\%, 95.9\%, and $98.2 \%$ of $\mathrm{N}, \mathrm{P}$, and $\mathrm{K}$ were allocated to leaves and stems, respectively. While afterward N, P, and K allocated to leaves and stems gradually decreased and at 100 DAT $45.8 \%$ of $\mathrm{N}, 44.5 \%$ of $\mathrm{P}$, and $48.7 \%$ of $\mathrm{K}$ were allocated in the fruit and $1.3 \%, 1.6 \%$, and $1.1 \%$ of $\mathrm{N}, \mathrm{P}$, and $\mathrm{K}$ were allocated in the roots, respectively (Table 2). Therefore, during the vegetative phase, nutrients were allocated mainly to the leaves and stems, which together constituted the largest portion of the total plant DW. Whereas, after fruit setting, as fruit DW increased, fruit became the major sink of the nutrients (Huett and Dettmann, 1988). During this phase, nutrients were also remobilized from the metabolic (leaves) and structural (stems) compartments of the plant to be reallocated in the fruit (Hill, 1980; Le Bot et al., 1997; Tei et al., 2002), as demonstrated by the overtime decline of the nutrients concentration in the leaves and stems (Fig. 3). These results highlight the fact that in seepageirrigated tomato crops, although the fertilizer is applied in pretransplanting, the crop nutrient demand becomes substantial only after 60 DAT. The nonsynchrony between nutrient supply and nutrient demand is therefore critical especially for $\mathrm{N}$ and $\mathrm{K}$, and the occurrence of leaching rainfall events and/or temporary flooding during the first 60 DAT can substantially affect the crop performances and NUE. Therefore, as suggested by Fraisse et al. (2010), depending on the planting date and season the $\mathrm{N}$ fertilization should be adjusted on the basis of the forecast risk of leaching rainfall in the specific season. In this perspective, data collected in this study may be also useful to calibrate and validate under Florida conditions decision support systems that are increasingly proposed as BMP tools for the irrigation and fertilizer management of tomato crops (Conversa et al., 2015).

Nitrogen nutrition index. The crop $\mathrm{N}$ status is considered optimal when the NNI is equal to 1 (Lemaire et al., 2008), values lower than 1 indicates crop $\mathrm{N}$ deficiency, while values above 1 suggest $\mathrm{N}$ excess and luxury consumption. During the spring, at 30 and 60 DAT, the NNI was close to 1 regardless of the $\mathrm{N}$ rate, suggesting that both $\mathrm{N}$ rates provided sufficient $\mathrm{N}$ for the first half of the crop cycle, with no $\mathrm{N}$ luxury consumption. At $90 \mathrm{DAT}$, the NNI was significantly $(P=0.05)$ affected by the $\mathrm{N}$ rate, and while the UF/IFAS $\mathrm{N}$ rate ensured an optimal NNI (0.99), the CG N rate showed a NNI $20 \%$ above the optimal value indicating an excess of $\mathrm{N}$ accumulation. Afterward, at $120 \mathrm{DAT}$, the $\mathrm{CG} \mathrm{N}$ rate ensured an optimal NNI, whereas the UF/IFAS $\mathrm{N}$ rate showed a significantly lower NNI $(P=$ $0.02), 15 \%$ below the optimal value indicating a light $\mathrm{N}$ deficiency at the end of the crop season. In the winter season, the NNI was always slightly above 1 for both $\mathrm{N}$ rates, and at 100 DAT was significantly higher $(P=0.05)$ with the $C G$ than with the UF/IFAS $\mathrm{N}$ rate $(1.35$ vs. 1.15$)$ indicating an excess of N. Overall, the NNI index indicates that in the spring season both tested rates ensured an optimal crop $\mathrm{N}$ status, and only at the end of the season a slight $\mathrm{N}$ deficiency was observed in plants fertilized with the UF/IFAS $\mathrm{N}$ rate. While in the winter season, an excess of $\mathrm{N}$ was observed with both $\mathrm{N}$ rates, nevertheless the higher accumulation of $\mathrm{N}$ observed with the application of the $\mathrm{CG} N$ rate resulted in a significantly higher $(P=$ 0.03 ) total marketable yield as compared with plants fertilized with the UF/IFAS N rate. These results suggest that greater yield is associated with higher $\mathrm{N}$ accumulation at the end of the season. Either the $\mathrm{N}$ sufficiency level is too low at and after 90 DAT

Table 4. Preplant soil nutrient content, nutrient recovery (REC), partial factor of productivity (PFP), and nutrient return as crop residues (RET) in seepage-irrigated 'Florida $47 \mathrm{R}$ ' tomato grown with two $\mathrm{N}$ rates during the spring and winter season of 2006 in Immokalee, FL. ${ }^{\mathrm{z}}$

\begin{tabular}{|c|c|c|c|c|c|c|c|c|c|c|c|c|}
\hline & \multicolumn{3}{|c|}{ Preplant soil nutrient content ${ }^{\mathrm{y}}$} & \multicolumn{3}{|c|}{$\mathrm{REC}^{\mathrm{x}}$} & \multicolumn{3}{|c|}{$\mathrm{PFP}^{\mathrm{w}}$} & \multicolumn{3}{|c|}{$\mathrm{RET}^{\mathrm{v}}$} \\
\hline & $\mathrm{N}$ & $\mathrm{P}$ & $\mathrm{K}$ & $\underline{\mathrm{N}_{\mathrm{REC}}}$ & $\mathrm{P}_{\mathrm{REC}}$ & $\overline{K_{\mathrm{REC}}}$ & $\mathrm{PFP}_{\mathrm{N}}$ & $\mathrm{PFP}_{\mathrm{P}}$ & $\mathrm{PFP}_{\mathrm{K}}$ & $\mathrm{N}$ & $\mathrm{P}$ & $\mathrm{K}$ \\
\hline & \multicolumn{3}{|c|}{$\mathrm{kg} \cdot \mathrm{ha}^{-1}$} & \multicolumn{3}{|c|}{$\%$} & \multicolumn{3}{|c|}{$\mathrm{kg}$ fresh fruit per $\mathrm{kg}$ of applied $\mathrm{N}, \mathrm{P}, \mathrm{K}$} & \multicolumn{3}{|c|}{$\mathrm{kg} \cdot \mathrm{ha}^{-1}$} \\
\hline \multicolumn{13}{|l|}{$\bar{N}$ rate $\left(\mathrm{kg} \cdot \mathrm{ha}^{-1}\right)$} \\
\hline 358 & 8.5 & 457 & 67.5 & 53 & 12 & 49 & 254 & 1,550 & 171 & 108 & 26 & 98 \\
\hline \multicolumn{13}{|l|}{ Season } \\
\hline Spring & 4 & 337 & 81 & 57 & 14 & 40 & 360 & 1,653 & 182 & 84 & 18 & 47 \\
\hline Winter & 13 & 577 & 54 & 57 & 10 & 52 & 258 & 1,290 & 142 & 115 & 36 & 161 \\
\hline Season & - & - & - & 0.94 & 0.02 & 0.07 & 0.04 & 0.04 & 0.04 & 0.02 & 0.004 & 0.03 \\
\hline $\mathrm{N}$ rate $\times$ season & - & - & - & 0.18 & 0.81 & 0.13 & 0.50 & 0.28 & 0.28 & 0.60 & 0.58 & 0.40 \\
\hline
\end{tabular}

${ }^{2}$ Reported values are averages of three replications. Means in bold are significantly different at $P=0.05$.

${ }^{\mathrm{y}}$ Calculated on a field basis based on $\mathrm{N}$ as the sum of $2 \mathrm{~mol} \cdot \mathrm{L}^{-1} \mathrm{KCl}$-extractable $\mathrm{NH}_{4}{ }^{+}-\mathrm{N}$ and $\mathrm{NO}_{3}{ }^{-} \mathrm{N}$, $\mathrm{P}$, and $\mathrm{K}$ as Mehlich-1 extractable $\mathrm{P}$ and $\mathrm{K}$.

${ }^{x} N_{R E C}, P_{R E C}, K_{R E C}=$ nitrogen $(N)$, phosphorous $(P)$, and potassium $(K)$ recovery, respectively.

${ }^{{ }} \mathrm{PFP}_{\mathrm{N}}, \mathrm{PFP}_{\mathrm{P}}, \mathrm{PFP}_{\mathrm{K}}=$ partial factor of productivity of applied $\mathrm{N}, \mathrm{P}$, and $\mathrm{K}$, respectively.

${ }^{\mathrm{N}} \mathrm{N}, \mathrm{P}$, and $\mathrm{K}$ return to the soil as crop residues, calculated as the sum of N, P, and K accumulated in roots, stems, and leaves at the end of each season. 


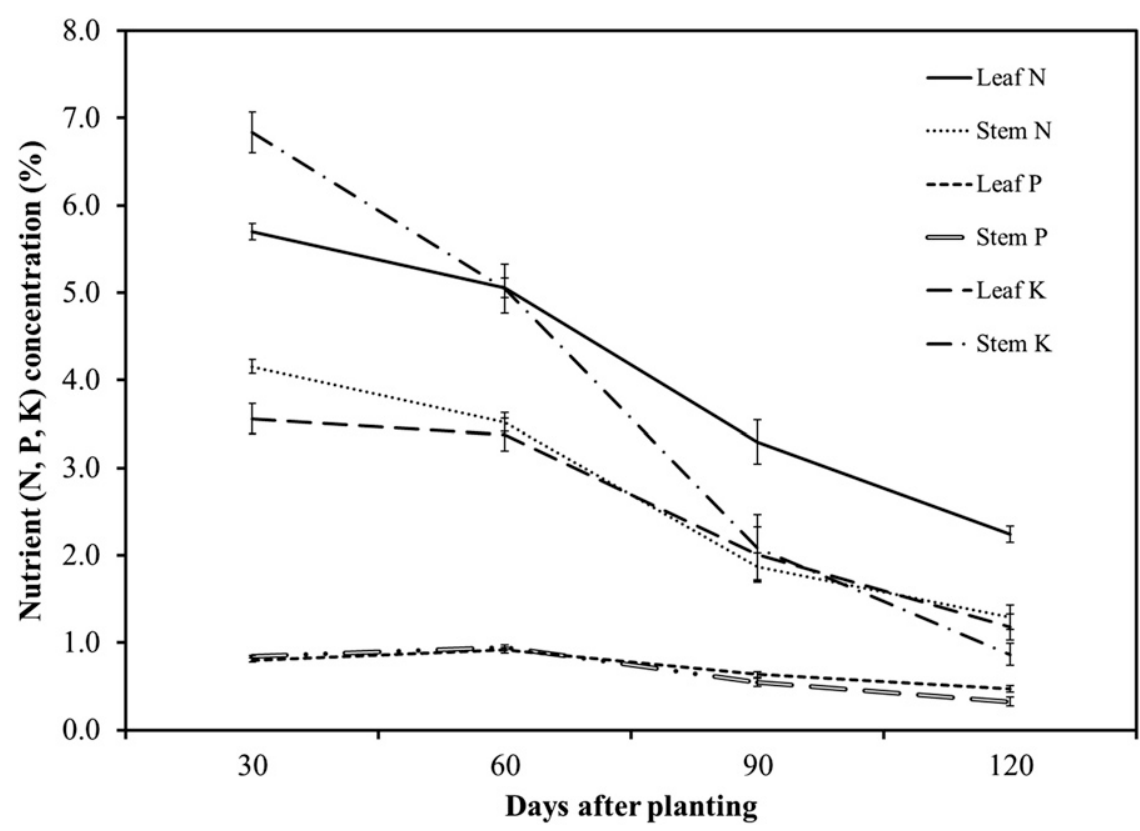

Fig. 3. Leaves' and stem's nitrogen $(\mathrm{N})$, phosphorous $(\mathrm{P})$, and potassium $(\mathrm{K})$ concentrations in seepageirrigated 'Florida $47 \mathrm{R}$ ' tomato grown during the spring season of 2006 in Immokalee, FL. Means of three replications. Vertical bars represent $\pm \mathrm{SE}$.

or insufficient fertilizer is recommended during the spring season to grow an optimum yield.

Preplant soil nutrient content, REC, PFP, and RET. Season preplant TN, TM1-P, and TM1-K were 4,337 , and $81 \mathrm{~kg} \cdot \mathrm{ha}^{-1}$, respectively, in the spring, and 13,557 , and 54 $\mathrm{kg} \cdot \mathrm{ha}^{-1}$, respectively, in the winter (Table 4). Estimated $\mathrm{N}$ deriving from mineralization was $96 \mathrm{~kg} \cdot \mathrm{ha}^{-1}$ in the spring and $75 \mathrm{~kg} \cdot \mathrm{ha}^{-1}$ in the winter. $\mathrm{N}$ mineralization was adapted from the average $\mathrm{N}$ mineralization rates estimated as total $\mathrm{N}$ extracted using the EUF method from soil types similar to Holopaw and Oldsmar for the spring and winter seasons, respectively (Dou et al., 2000).

No significant interaction was observed between $\mathrm{N}$ rate and seasons for the nutrient REC, PFP, and nutrient return, therefore the data of the two seasons were analyzed together (Table 4). The $\mathrm{N}_{\text {REC }}$ was significantly higher $(P=0.01)$ with UF/IFAS $\mathrm{N}$ rate than with $\mathrm{CG} \mathrm{N}$ rate, while it was not significantly affected $(P=0.94)$ by the season. Observed $\mathrm{N}_{\mathrm{REC}}$ values were comparable to those estimated by Scholberg et al. (2000) in seepage-irrigated tomato grown in central Florida $(48 \%$ and $61 \%$, with $\mathrm{N}$ rates of 200 and $300 \mathrm{~kg} \cdot \mathrm{ha}^{-1}$, respectively), whereas were higher than values recorded in the same study for drip-irrigated tomato grown in north Florida (46\% and $36 \%$, with $\mathrm{N}$ rates of 200 and $300 \mathrm{~kg} \cdot \mathrm{ha}^{-1}$, respectively). Observed $\mathrm{N}_{\mathrm{REC}}$ values were also similar to those estimated by Elia and Conversa (2012) in drip-irrigated processing tomato (on average $70.5 \%$ and $55 \%$ with 200 and $300 \mathrm{~kg} \cdot \mathrm{ha}^{-1}$ of $\mathrm{N}$, respectively) grown in silty-clay soils in a semiarid environment with similar $\mathrm{N}$ rates, and to those estimated by Zotarelli et al. (2009a) for drip-irrigated tomato (ranging on average from $56.2 \%$ to $66.4 \%$ and from $42.1 \%$ to $50.3 \%$ with 220 and $330 \mathrm{~kg} \cdot \mathrm{ha}^{-1}$
$553 \mathrm{~kg} \cdot \mathrm{ha}^{-1}$ of $\mathrm{K}$, a rate commonly used by the tomato industry in Florida, while based on the preplant TM1-K levels the UF/IFAS K recommended rates were 93 and $139 \mathrm{~kg} \cdot \mathrm{ha}^{-1}$ in spring and winter season, respectively (Olson et al., 2005). Given the high mobility of $\mathrm{K}$ in sandy soils and the high risk of $\mathrm{K}$ leaching under Florida weather conditions, especially in seepage-irrigated crops (Sato et al., 2009b), the relatively low $\mathrm{K}_{\mathrm{REC}}$ values observed in this study suggest that lower $\mathrm{K}$ rates could be used.

The PFP, expressed as marketable fresh fruit yield per kilogram of applied N, P, and $\mathrm{K}$ were significantly affected by both $\mathrm{N}$ rates and seasons (Table 4). While the $\mathrm{PFP}_{\mathrm{N}}$ of plants fertilized with the UF/IFAS $\mathrm{N}$ rate was significantly higher $(P=0.001)$ than that of plants fertilized with $C \mathrm{G}$ rate, $\mathrm{PFP}_{\mathrm{P}}$, and $\mathrm{PFP}_{\mathrm{K}}$ were significantly higher $(P=0.04)$ at higher $\mathrm{N}$ rate. This may be explained by the significantly higher fruit yield produced by plants fertilized with CG $\mathrm{N}$ rate as compared with those fertilized at UF/IFAS $\mathrm{N}$ rate. As expected, the $\mathrm{PFP}_{\mathrm{N}}, \mathrm{PFP}_{\mathrm{P}}$, and $\mathrm{PFP}_{\mathrm{K}}$ were significantly $(P=0.04)$ higher $(39.5 \%, 28.1 \%$, and $28.2 \%$, respectively) in the spring than in the winter season.

At the end of the season, $\mathrm{N}, \mathrm{P}$, and $\mathrm{K}$ return to the soil with the crop residues was significantly higher $(P<0.03)$ in the winter than in the spring, which may be explained in part by the lower harvest index observed in the winter as compared with the spring season, and in part by the different partitioning of the shoot DW between leaves and stems. In the winter season, it was observed in fact, a larger proportion of leaf biomass, characterized by higher nutrient concentration as compared with the stem. Vice versa in the spring, the proportion of stem was relatively higher. The $\mathrm{N}$ rates did not significantly affect $\mathrm{P}$ and $\mathrm{K}$ return to the soil, whereas $\mathrm{N}$ return was significantly higher $(P=0.02)$ with CG N rate than with UF/IFAS $\mathrm{N}$ rate $\left(108\right.$ vs. $\left.91 \mathrm{~kg} \cdot \mathrm{ha}^{-1}\right)$.

In conclusion, the results of this study highlight that the crop response to $\mathrm{N}$ input is influenced by the growing season, possibly because of the different length of the seasons, radiation levels, and temperatures. Longer growing seasons, especially if characterized by concomitant higher solar radiation and temperatures, are associated to higher biomass production and fruit yields, and since nutrients accumulation is strictly related to the crop dry biomass production, in extended growing seasons, also the crop $\mathrm{N}$ requirement is higher. Therefore, UF/IFAS $\mathrm{N}$ fertilizer recommendations should be season specific and possibly adjustable on the basis of the planting date and of the foreseen risk of leaching rainfall events. However, additional investigation must be considered to substantiate these conclusions, and further studies with $\mathrm{N}$ rates higher than the UF/IFASrecommended rate should include an environmental and economic analysis. Furthermore, given the low $\mathrm{P}$ and $\mathrm{K}$ recovery levels a greater effort should be made to improve the management of these nutrients. 


\section{Literature Cited}

Cantliffe, D., P. Gilreath, D. Haman, C. Hutchinson, Y. Li, G. McAvoy, K. Migliaccio, T. Olczyk, S. Olson, D. Parmenter, B. Santos, S. Shukla, E. Simonne, C. Stanley, and A. Whidden. 2009. Review of nutrient management systems for Florida vegetable producers: A white paper from the UF/IFAS Vegetable Fertilizer Task Force. Univ. Florida, IFAS, EDIS Publ. HS1156. 6 June 2015. <http://edis.ifas.ufl.edu/hs1156>.

Cockx, E.M. and E.H. Simonne. 2014. Reduction of the impact of fertilization and irrigation on processes in the nitrogen cycle in vegetable fields with BMPs. Univ. Florida, IFAS, EDIS Publ. HS948. 6 June 2015. <http://edis.ifas.ufl.edu/hs201>.

Conversa, G., A. Bonasia, F. Di Gioia, and A. Elia. 2015. A decision support system ( $\mathrm{Ges} \mathrm{CoN})$ for managing fertigation in vegetable crops. Part II-Model calibration and validation under different environmental growing conditions on field grown tomato. Front. Plant Sci. 6:495.

Devienne-Barret, F., E. Justes, J.M. Machet, and B. Mary. 2000. Integrated control of nitrate uptake by crop growth rate and soil nitrate availability under field conditions. Ann. Bot. (Lond.) 86:905-1005.

Dou, H., A.K. Alva, and T. Appel. 2000. An evaluation of plant-available soil nitrogen in selected sandy soils by electro-ultrafiltration, $\mathrm{KCl}$, and $\mathrm{CaCl}_{2}$ extraction methods. Biol. Fertil. Soils 30:328-332.

Dukes, M.D., L. Zotarelli, and K.T. Morgan. 2010. Use of irrigation technologies for vegetable crops in Florida. HortTechnology 20:133-142.

Elia, A. and G. Conversa. 2012. Agronomic and physiological responses of a tomato crop to nitrogen input. Eur. J. Agron. 40:64-74.

Florida Department of Agriculture and Consumer Services (FDACS). 2005. Water quality/quantity best management practice manual for Florida vegetable and agronomic crops. 6 June 2015. <http://www.freshfromflorida. com/content/download/32110/789059/Bmp_ VeggieAgroCrops2005.pdf $>$.

Fraisse, C.W., Z. Hu, and E.H. Simonne. 2010. Effect of El Niño-Southern oscillation on the number of leaching rain events in Florida and implications on nutrient management for tomato. HortTechnology 20:120-132.

Gastal, F. and G. Lemaire. 2002. N uptake and distribution in crops: An agronomical and ecophysiological perspective. J. Expt. Bot. 53:789-799.

Greenwood, D.J., F. Gastal, G. Lemaire, A. Draycott, P. Millard, and J.J. Neeteson. 1991. Growth rate and $\% \mathrm{~N}$ of field grown crops: Theory and experiments. Ann. Bot. (Lond.) 67:181-190.

Hill, J. 1980. The remobilization of nutrients from leaves. J. Plant Nutr. 2:407-444.

Hochmuth, G. and E. Hanlon. 2014. A summary of $\mathrm{N}, \mathrm{P}$, and $\mathrm{K}$ research with tomato in Florida. Univ. Florida, IFAS, EDIS Publ. SL355. 6 June 2015. <http://edis.ifas.ufl.edu/cv236>.

Huett, D.O. and E.B. Dettmann. 1988. Effect of nitrogen on growth, fruit quality and nutrient uptake of tomatoes grown in sand culture. Austral. J. Exp. Agr. 28:391-399.

Jones, J.B., Jr., and V.W. Case. 1990. Sampling, handling, and analyzing plant tissue samples, $\mathrm{p}$. 389-415. In: R.L. Westerman (ed.). Soil testing and plant analysis. 3rd ed. SSSA Book Ser. 3 . SSSA, Madison, WI.

Kopp, J.F. and G.D. McKee. 1983. EPA method 351.2: Determination of total Kjeldahl nitrogen by semi-automated colorimetry. In: Methods for chemical analysis of water and wastes. USEPA Rep. 600/4-79/020. U.S. Govt. Print Office, Washington, DC.

Le Bot, J., J.L. Andriolo, C. Gary, S. Adamowicz, and P. Robin. 1997. Dynamics of N accumulation and growth of tomato plants in hydroponics: An analysis of vegetative and fruit compartments, p. 37-51. In: G. Lemaire and I. Burns (eds.). Diagnostic procedures for crop N management, Colloques de 1'INRA, Vol. 82. INRA Editions, Paris, France.

Lemaire, G., F. Gastal, and J. Salette. 1989. Analysis of the effect of $\mathrm{N}$ nutrition on dry matter yield of a sward by reference to potential yield and optimum N content. Proc. XVI Int. Grassland Congress, Nice, France. p. 179-180.

Lemaire, G., M-H. Jeuffroy, and F. Gastal. 2008. Diagnosis tool for plant and crop $\mathrm{N}$ status in vegetative stage. Theory and practices for crop $\mathrm{N}$ management. Eur. J. Agron. 28:614-624.

Locascio, S.J. 2005. Management of irrigation for vegetables: Past, present, and future. HortTechnology 15:482-485.

Mehlich, A. 1978. New extractant for soils test evaluation of phosphorus, potassium, magnesium, calcium, sodium, manganese and zinc. Commun. Soil Sci. Plant Anal. 9:477-492.

Mulvaney, R.L. 1996. Nitrogen: Inorganic forms. In: D.L. Sparks (ed.). Methods of soil analysis: Part 3 Chemical methods, p. 1123-1184. SSSA Book Ser. 5, SSSA, Madison, WI.

Olson, S.M., D.N. Maynard, G.J. Hochmuth, C.S Vavrina, W.M. Stall, M.T. Momol, S.E. Webb, T.G. Taylor, S.A. Smith, and E.H. Simonne. 2005. Tomato production in Florida. In: S.M. Olson and E. Simonne (eds.). 2005-2006 vegetable production handbook for Florida, p. 357 375. Vance Publishers, Lenexa, KS.

Ozores-Hampton, M.P., E.J. McAvoy, M. Lamberts, and D. Sui. 2010. A survey of the effectiveness of current methods used for the freeze protection of vegetables in South Florida. Proc. Fla. State Hort. Soc. 123:128-133.

Ozores-Hampton, M.P., E. Simonne, E. McAvoy, F. Roka, P. Stansly, S. Shukla, P. Roberts, K. Morgan, K. Cushman, T. Obreza, P. Gilreath, and D. Parmenter. 2006. Nitrogen Best Management Practice with tomato production in Florida in the 2005-2006 season. Proc. Fla. State Hort. Soc. 119:284-288.

Ozores-Hampton, M., E. Simonne, F. Roka, K. Morgan, S. Sargent, C. Snodgrass, and E. McAvoy. 2012. Nitrogen rates effects on the yield, nutritional status, fruit quality, and profitability of tomato grown in the spring with subsurface irrigation. HortScience 47:1129-1133.

Sato, S., K.T. Morgan, M. Ozores-Hampton, and E.H. Simonne. 2009a. Spatial and temporal distributions in sandy soils with seepage irrigation: I. Ammonium and nitrate. Soil Sci. Soc. Amer. J. 73:1044-1052.

Sato, S., K.T. Morgan, M. Ozores-Hampton, and E.H. Simonne. 2009b. Spatial and temporal distributions in sandy soils with seepage irrigation: II. Phosphorus and potassium. Soil Sci. Soc. Amer. J. 73:1053-1060.

Sato, S., K.T. Morgan, M. Ozores-Hampton, K. Mahmoud, and E.H. Simonne. 2012. Nutrient balance and use efficiency in sandy soils cropped with tomato under seepage irrigation. Soil Sci. Soc. Amer. J. 76:1867-1876.

Scholberg, J., B.L. McNeal, K.J. Boote, J.W. Jones, S.J. Locascio, and S.M. Olson. 2000. Nitrogen stress effects on growth and nitrogen accumulation by field-grown tomato. Agron. J. 92:159-167.

Smajstrla, A.G. and R. Muñoz-Carpena. 2011. Simple water level indicator for seepage irrigation. Univ. Florida, IFAS, EDIS Publ. AE085. 6 June 2015. <http://edistt.ifas.ufl.edu/pdffiles/ AE/AE08500.pdf $>$.

Simonne, E., C. Hutchinson, J. DeValerio, R. Hochmuth, D. Treadwell, A. Wright, S. Bielinski, A Whidden, E. McAvoy, X. Zhao, T. Olczyk, A. Gazula, and M. Ozores-Hampton. 2010. Current knowledge, gaps, and future needs for keeping water and nutrients in the root zone of vegetables grown in Florida. HortTechnology 20:143-152.

Simonne, E.H. and B. Morgant. 2005. Denitrification in seepage irrigated vegetable fields in south Florida. Univ. Florida, IFAS, EDIS Publ. HS1004. 6 June 2015. <http://edis.ifas.ufl.edu/ hs $248>$.

Simonne, E. and M. Ozores-Hampton. 2006. Challenges and opportunities for extension educators involved in best management practices. HortTechnology 16:403-407.

Simonne, A.H., E.H. Simonne, R.R. Eitenmiller, H.A. Mills, and C.P. Cresman. 1997. Could the dumas method replace the Kjeldahl digestion for nitrogen and crude protein determinations in foods? J. Sci. Food Agr. 73:39-45.

Stanley, C.D. and G.A. Clark. 2003. Effect of reduced water table and fertility levels on subirrigated tomato production in southwest Florida. Fla. Coop. Ext. Serv. SL 210. Inst. of Food and Agr. Sci., Univ. Florida, Gainesville, FL.

Tei, F., P. Benincasa, and M. Guidici. 2002. Critical nitrogen concentration in processing tomato. Eur. J. Agron. 18:45-56.

Tiessen, H. and J.O. Moir. 1993. Characterization of available $\mathrm{P}$ by sequential extraction. In: M.R. Carter (ed.). Soil sampling and methods of analysis, p. 75-86. Lewis Publishers, Boca Raton, FL.

U.S. Department of Agriculture (USDA). 1997. United States standards for grade of fresh tomatoes. U.S. Dept. Agr., Agriculture Marketing Service. Washington, DC.

U.S. Department of Agriculture (USDA). 2015 Vegetable 2014 summary. U.S. Dept. Agr., National Agricultural Statistics Service, Washington, DC. 6 June 2015. <http://usda.mannlib. cornell.edu/usda/current/VegeSumm/VegeSumm01-29-2015.pdf $>$.

U.S. Environmental Protection Agency. 2010 Clean water act. 6 June 2015. <http://www. epa.gov/agriculture/lcwa.html $>$.

Zotarelli, L., M.D. Dukes, J.M.S. Scholberg, R. Muñoz-Carpena, and J. Icerman. 2009a. Tomato nitrogen accumulation and fertilizer use efficiency on a sandy soil, as affected by nitrogen rate and irrigation scheduling. Agr. Water Mgt. 96:1247-1258.

Zotarelli, L., J.M.S. Scholberg, M.D. Dukes, R Muñoz-Carpena, and J. Icerman. 2009b. Tomato yield, biomass accumulation, root distribution and irrigation water use efficiency on a sandy soil, as affected by nitrogen rate and irrigation scheduling. Agr. Water Mgt. 96:23-34.

Zotarelli, L., L. Rens, C. Barret, D.J. Cantliffe, M. D. Dukes, M. Clark, and S. Lands. 2013. Subsurface drip irrigation (SDI) for enhanced water distribution: SDI-Seepage Hybrid System. Univ. Florida, IFAS, EDIS Publ. HS1217. 6 June 2015. <http://edis.ifas.ufl.edu/hs1217>. 